\title{
RISYWAH DALAM PERSPEKTIF HADIS
}

\author{
Ahmad Jurin Harahap \\ Mahasiswa Pascasarjana Universitas Islam Negeri \\ Sunan Gunung Djati \\ Bandung \\ J1. Soekarno Hatta no.748, kota Bandung, Jawa Barat \\ Email: ahmad.jurin@gmail.com
}

\begin{abstract}
Abstrak
Risywah merupakan pemberian hadiah kepada pegawai pemerintahan dengan harapan segala keinginan penyuap diloloskan kasusnya atas musuhnya di pengadilan. Sesuatu yang didapatkan oleh masyarakat dari seseorang yang mengharapkan manfaat dari masyarakat tersebut, kadang dianggap sebagai suatu pemberian yang biasa saja, karena mereka tidak bisa membedakan mana kategori suap dan mana pemberian, karena kita sebagai masyarakat awam banyak yang tidak mengerti adanya kasus seperti ini, kita beranggapan ini hanyalah pemberian atau hadiah yang sifatnya sebagai ungkapan rasa terima kasih atas kesediaannya memberikan dukungan kepada calon kepalanya. Padahal antara hadiah dan suap cukup jauh berbeda. Hadis risywah yang yang menjadi fokus pembahasan dalam penelitian ini berkualitas shahih. Dengan demikian hadis tersebut dapat diterima dan dijadikan dalil. Pemberian yang dibolehkan dalam Islam adalah berbentuk hibah. Pada dasarnya hukum transaksi muamalah lainnya bahwa hibah adalah perkara mubah jika selama dalam bentuknya tidak melanggar apa yang disebutkan Allah Swt dan Rasulnya tentang pelanggaran yang menyerupai risywah.
\end{abstract}

\section{Keyword: Risywah, Perspektif, Hadis.}

\section{A. PENDAHULUAN}

Islam telah melarang seorang Islam menyuap penguasa dan pembantu pembantunya. Begitu juga penguasa dan membantunya dilarang menerima suap tersebut. Firman Allah dalam surah albaqarah ayat 188 :

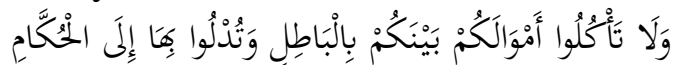

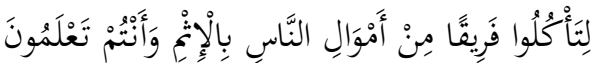

Dan janganlah kamu makan harta benda kamu diantara kamu dengan bathil dan janganlah kamu menyuap dengan harta itu kepada para hakim, dengan maksud supaya kamu dapat memakan sebagian harta orang lain itu dengan jalan dosa, padahal kamu mengetahui.( al-baqarah ayat 188) ${ }^{1}$

Hukum Islam yang disyariatkan Allah Swt pada hakekatnya diproyeksikan untuk kemaslahatan manusia. Salah satu kemaslahatan yang hendak direalisasikan adalah terpeliharanya harta dari pemindahan hak milik yang menyimpang dari prosedur

1 Al-Qur'an yang digunakan dalam tulisan ini adalah yang diterbitkan oleh Departemen Agama RI, Mushaf Mufassir, ( Bandung : Jabal, 2009), 29. hukum, dan dari pemanfaatannya yang tidak sesuai dengan kehendak-Nya.

Tanpa mengecilkan arti atau signifikasi dari semangat berdemokrasi masyarakat melalui pilkada, berbagai dampak negatif pun muncul seperti ambisi yang berlebihan terhadap jabatan sehingga cenderung menghalalkan segala cara, melalui risywah (suap) dan kampanye negatif negative campaign .2

Risywah (suap) merupakan penyakit kronis sosial bagaikan penyakit kanker dalam dunia medis. Penyakit umat yang rumit disembuhkan. Dia mengacaukan tatanan sosial, menjungkir balikkan nilai humanisme. Disamping itu risywah mampu menggerogoti nilai dan moral ummat secara perlahan tetapi pasti. Mengesampinkan $k a f a$ 'ah potensi) ummat dan juga menyianyiakan kemaslahatan umum. ${ }^{3}$ Risywah

2 Muhammad Ulul Azmi, Pilkada dan Risywah Dalam Perspektif Siyasah Syar'iyyah, Skripsi S1 Fakultas Syari'ah dan Hukum, (Yogyajakarta : Fakultas Syari'ah dan Hukum UIN Kalijaga, 2010), 2.

3 Muhammad Ulul Azmi, Pilkada dan Risywah Dalam Perspektif Siyasah Syar'iyyah, 3. 
mampu membentuk syahsiah individualistis, materialis, bermental hipokrit, penghinat, tamak, dan tega dengan sesama. Dia dapat memicu masyarakat bertindak kriminal, perampokan, pemerasan dan bahkam dendam berkepanjangan ${ }^{4}$

Risywah (suap) menurut undang-undang republik Indonesia adalah:

"Barangsiapa memberikan hadiah kepada pengawai perintah atau hakim dengan harapan segala keinginan penyuap diloloskan atau dimenangkan kasusnya atas musuhnya di pengadilan, meskipun hal tersebut menyalahi ketentuan jabatan dan wewenang penerima suap." 5

Dari sudut pandangan hukum Islam, wawasan masyarakat sangat terbatas mengenai masalah risywah. Sebagian masyarakat beranggapan bahwa risywah bukanlah sebuah kejahatan, tetapi kesalahan kecil, walaupun mengetahui bahwa risywah adalah terlarang, namun mereka tidak berduli dengan larangan tersebut. Apalagi karena terpengaruh dengan keuntungan yang didapatkan. Padahal Rasulullah saw telah mengingatkan dalam sabdanya:

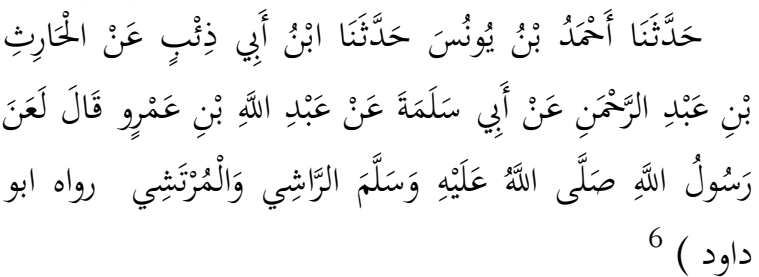

Ahmad bin Yunus menceritakan kepada kami, Ibnu Abi Dzi'bi menceritakan kepada kami, dari Harits bin Abdurrahman, dari Abi Salamah, dari Abdullah bin Umar berkata, bahwa Rasulullah Saw bersabda: "Rasulullah shallallahu 'alaihi wasallam melaknat orang yang menyuap dan yang menerima suap." H.R. Abu Daud .

Sesuatu yang didapatkan oleh masyarakat dari seseorang yang mengharapkan manfaat atau imbalan dari masyarakat tersebut,

${ }^{4}$ Abu Abdul Halim Ahmad, Dampak Suap dan Bahayanya Tinjauan Syari'ah dan Sosial, (Jakarta : Pustaka al-Kautsar, 1996), 11-12.

5 Abu Abdul Halim Ahmad, Dampak Suap dan Bahayanya Tinjauan Syari'ah dan Sosial.

6 Abu Daud Sulaiman bin al-Asy'ats alSijistani, Sunan Abi Daud, (Beirut : Maktabah Ashriyah, 2003), jilid 3, 291. kadang-kadang dianggap sebagai suatu pemberian yang biasa-biasa saja, karena mereka tidak bisa membedakan mana yang termasuk kategori suap dan mana yang termasuk kategori pemberian, karena kita sebagai masyarakat awam banyak yang tidak mengerti adanya kasus-kasus seperti ini, kita beranggapan ini hanyalah pemberian atau hadiah yang sifatnya sebagai ungkapan rasa terima kasih atas kesediaannya memberikan dukungan kepada calon kepala negara tersebut.

Padahal antara hadiah dan suap cukup jauh berbeda. Hadiah adalah sesuatu yang diberikan kepada orang lain karena sikap memuliakan dan rasa cinta. ${ }^{7}$ Nilai luhur Islam mendorong setiap muslim untuk selalu gemar memberikan hadiah kepada orang lain. Karena memberi hadiah ini dapat memicu lahirnya rasa cinta dan kasih sayang diantara sesama. Sebagaimana disebutkan dalam hadis:

$$
\begin{aligned}
& \text { حدثنا سويد بن سعيد ، حدثنا ضمام ، عن موسى بن }
\end{aligned}
$$

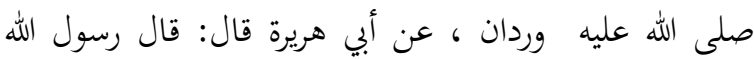

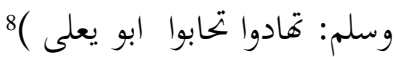

Suwai bin Said menceritakan kepada kami, Dhamam menceritakan kepada kami, dari Musa bin Wirdan dari Abu Hurairah ra, dari Nabi Saw, beliau bersabda: "Saling memberi hadiahlah kalian, niscaya kalian saling mencinta”.( H. R. Abu Ya'la .

Namun demikian, tidak semua praktek memberi dan menerima hadiah dapat dibenarkan dalam syari'at Islam. Di antara hadiah yang tidak diperbolehkan dalam Islam adalah hadiah yang diberikan untuk pengendali kebijakan, pemegang wewenang dan otoritas, orang yang bertugas menjalankan pelayanan publik dan hakim yang hendak memutuskan suatu perkara. Hal ini disebabkan oleh motivasi dan tujuan yang tersembunyi dari pemberi hadiah tersebut.

Secara umum ulama membolehkan suap dengan tujuan untuk memeperjuangkan hak

7 Ibrahim Mustafa \& Dkk, al-Mu'jam alWasith, (Istanbul : Al-Maktabah al -Islamiyah, 1972), 979.

8 Abu Ya'la, Musnad Abu Ya'la, (Beirut : Dar al-Ilm al-Malayin, t.thn), jilid 5, 375. 
atu menolak kezaliman yang menganzam keselamatan diri seseorang. Masalahnya, jika budaya ini dipraktekkan di Indonesia yang sedang berusahan keras memberantas korupsi, kolusi, dan nepotisme justru akan rentan sebab seseorang pasti akan berupaya mencari celah dan alasan agar bisa mendapat hak atau agar selamat dari ketidak adilan dan kezaliman sehingga akhirnya ia melakukan penyuapan kepada pejabat atau pihak yang berwenang. ${ }^{9}$

Jalur hukum yang ditempuh untuk mnghentikan budaya risywah atau suap nampaknya belum membuahkan hasil yang mengembirakan. Para penyuap belum sadar akibat perbuatannya. Oleh sebab itu, masalah risywah atau suap ini perlu disoroti melalui hadis nabi, sebab muatan nilai-nilai hadis Nabi melebihi hukum positif, bakan hadis Nabi tidak hanya berimplikasi hukum dunia saja, akan tetapi juga berimplikasi hukuman ukhrawi dosa) yang akan di pertanggung jawabkan diakhirat kelak.

Risywah termasuk perbuatan bathil, sedangkan asumsi mayoritas masyarakat praktek seperti ini dibolehkan oleh syara' dan semua itu merupakan kesalahan besar. Hal ini terjadi karena ketidakpahaman masyarakat terhadap makna risywah tersebut sesuai dengan yang di sampaikan dalam hadis nabi. Oleh sebab itu, untuk memudahkan masyarakat dalam memahami hadis tersebut penulis merasa perlu membahas kajian, "RISYWAH DALAM PERSPEKTIF HADIS NABI" sehingga diharapkan dapat memberikan titik terang terhadap permasalahan ini.

\section{B. PEMBAHASAN}

\section{Pengertian Risywah}

Pengertian risywah menurut etimologis berasal dari bahasa Arab "رشا يرشو" yang masdar شوة huruf ra-nya dibaca kasrah, fathah atau dhammah ) berarti الجع yaitu upah, hadiah, komisi atau suap. ${ }^{10}$ Ibnu Manzhur juga mengemukakan tentang

\footnotetext{
${ }^{9}$ Nurul Irfan, Korupsi dalam Hukum Pidana Islam, ( Jakarta : Amzah, 2012), 95.

${ }^{10}$ Ahmad Warson Munawwir, Kamus ArabIndonesia, (Surabaya : Pustaka Progressif, 2002 ), 501.
}

makna risywah, ia mengemukakan bahwa رشا الفرخ kata risywah terbentuk dari kalimat anak burung merengek-rengek ketika mengangkat kepalanya kepada induk untuk di suapi. ${ }^{11}$ Sedangkan di dalam Mu'jam alWasith mengemukan rasya al-farakhu, artinya anak puyuh itu menjulurkan kepalanya kepada induknya ${ }^{12}$

Adapun secara terminologi, Para fuqaha bervariasi memberikan definisi tentang risywah, di antaranya:

a. Al-'Asqalanị risywah adalah:

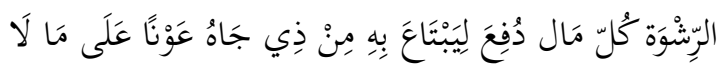

"setiap uang yang diberikan kepada pejabat sebagai kompensasi atas pertolongan yang batil." 13

b. Yusuf al-Qardhawi mengatakan, risywah adalah "uang yang diberikan kepada penguasa atau pegawai, supaya penguasa atau pegawai tersebut menjatuhkan hukuman yang menguntungkannya". ${ }^{14}$

c. Abdullah Bin Muhsin mengatakan risywah adalah sesuatu yang diberikan kepada seseorang dengan syarat orang yang diberi tersebut dapat menolak orang yang memberi. ${ }^{15}$

d. Sayyid Abu Bakr mendefinisikan risywah sebagai "Memberikan sesuatu agar hukum diputuskan secara tidak benar/tidak adil, atau untuk mencegah putusan yang benar atau adil."16

e. Abd al-Azhim Syam al-Haq, Risywah adalah "Sebuah perantara untuk dapat memudahkan urusan dengan pemberian

11 Muhammad ibnu Makram ibn Manzhur al-Afriki al-Mishri, Lisanul 'Arab, (Beirut : Dar alShadur, 1374 H), jilid ke- 14, 322.

${ }^{12}$ Ibrahim Mustafa \& Dkk, al-Mu'jam alWasith, (Istanbul : al-Maktabah al -Islamiyah, 1972), 347.

13 Ahmad bin 'Ali Ibn Hajar al- 'Asqalani, Fath al-Barị syarh Șahih al-Bukhari, (Riyaḍ : Dar alSalam, 2001 M/ $1421 \mathrm{H}$ ), jilid ke- 5, 311.

14 Yusuf al-Qarḍawị, al-Halalwa al-Haram fi al-Islam, (Beirut: al-Maktabah al-Islamiyah, 1980), h .320 .

15 Abdullah Bin Ab. Muhsin, Suap Dalam Pandangan Islam, trjmh. Muchotob Hamzah dan Subakir Saerozi, (Jakarta : Jakarta : Gema Insani Press, 2001), 9.

16 Sayyid Abu Bakr, I'anatuth Thalibin, (Semarang : Toha Putra, 2000), jilid ke-4, 261. 
sesuatu atau pemberian untuk membatalkan yang benar atau untuk membenarkan yang batil.'Penyuapan adalah dilakukan demi mengharapkan kemenangan dalam perkara yang diinginkan seseorang, atau ingin memudahkan seseorang dalam menguasai hak atas sesuatu. ${ }^{17}$

f. Ahmad Mukhtar dalam Mu'jam al-Lugah al-'Arabiyah al Mu'aşirah, risywah adalah "Pemberian yang tidak benar untuk kepentingan tertentu, atau untuk membenarkan yang salah (الباطل) dan menyalahkan yang benar (اللحق)" (الحل)" ${ }^{18}$

g. Al-Gharyani berpendapat, risywah adalah upaya untuk mendapatkan sesuatu dengan rekayasa dan membayarkan sejumlah uang. ${ }^{19}$

h. Sedangkan Nurul Irfan menyebutkan, risywah adalah sesuatu yang diberikan dalam rangka mewujudkan kemaslahatan atau sesuatu yan diberikan dalam rangka membenarkan yang salah atau menyalahkan yang benar. ${ }^{20}$

Menurut undang-undang republik Indonesi No. 11 tahun 1980 tentang tindak pidana suap, suap didefenisikan sebagai memberi atau menjanjikan sesuatu kepada seseorang dengan maksud untuk menbujuk supaya orang itu berbuat sesuatu atau tidak berbuat sesuatu dalam tugasnya yang berlawanan dengan kewenangan atau kewajiban yang menyangkut kepentingan umum. ${ }^{21}$

\section{Hadis-Hadis tentang Risywah}

Hadis yang berbicara tentang risywah diriwayatkan oleh banyak mukharij yang termuat dalam kitab-kitab hadis yang

${ }^{17}$ Tim Penulis Depdikbud RI, Kamus Besar Bahasa Indonesia, (Jakarta : Pustaka Panjimas, 1980), 720.

${ }^{18}$ Ahmad Mukhtar Umar, Mu'jam al-Lugah al- 'Arabiyah al-Mu'asirah, (Kairo : 'Alam al- Kutub, 2008), jilid 1, 897.

19 Al-Shadiq Abdurrahman al-Gharyani, Fatwa-Fatwa Muamalah Kontemporer, ( Surabaya : Pustaka Progresif, 2004), 123.

${ }^{20}$ Nurul Irfan. Korupsi dalam Hukum Pidana Islam, 89.

${ }^{21}$ Tim Penyusun Undang-Undang Republik Indonesia, Tindak Pidana Suap, www.pih.deplu.go.id, diakses 17/02/2013. mu'tabar. ${ }^{22}$ Hadis risywah setelah dilacak melalui kitab Mu'jam al-Mufahras li al-Faz al-Hadis dengan menggunakan kata Rasyâ diriwayatkan oleh Abu Daud dalam kitab Aqdhiyah bab no. 4, al-Tirmidzi dalam kitab Ahkam bab no. 9, Ibnu Majah dalam kitab Ahkam bab no. 2, dan Ahmad bin Hanbal jilid 2 halaman 164, 190, 194, 212, 387, 388 ,jilid 5 halaman $279 .{ }^{23}$ Sedangkan apa bila di lacak dengan menggunakan kitab Miftah Kunuz al-Sunnah iriwayatkan oleh Abu Daud kitab 23 bab 4, al-Tirmidzi kitab 13 bab 9, Ahmad bin Hanbal juz kedua h. 164, 190, 194, 212, 387, juz kelima h. 216. $779 .^{24}$

Kemudian jika di lacak dengan menggunakan kitab Jam'u al-Jawami' alMa'ruf Bi Jami' al-Kabir diriwayatkan oleh Ibnu Majah dan Abdul Razak dari Ibnu Umar. ${ }^{25}$ Selanjutnya jika di lacak dengan menggunakan kitab Tuhfaz al-Asyraf Bi Ma'rifat al-Athra diriwayatkan oleh alTirmidzi kitab ahkam, Abu Daud kitab Qahda', dan Ibnu Majah kitab ahkam. ${ }^{26}$

Adapun redaksi hadisnya adalah sebagai berikut:

1. Dalam kitab Abu Daud kitab Aqdhiyah bab no. 4

${ }^{22}$ Kitab-kitab hadis yang mu'tabar yaitu: Shahih Bukhari, Shahih Muslim, Sunan Abu Daud, Sunan al-Nasa'i, Sunan al-tirmidzi, Sunan al-Darimi, Sunan Ibnu Majah, Muwatta' Imam Malik, Musnad Ahmad Bin Hambal, lihat : Syuhudi Isma'il, Cara praktis Mencari Hadis, (Jakarta : Bulan Bintang, 1991), 51

${ }^{23}$ A.J Wensick, al-Mu'jam al-Mufahras li Alfas al-Hadist al-Nabawi (Laiden : Maktabah Briil, 1962), jilid 2, 262.

24 Muhammad Fu'ad Abdul Baqi, Miftah Kunuz al-Sunnah, (Kairo : Dar al-Hadis, 2007 M/1428 H), 253.

25 Jalaluddin al-Suyuthi, Jam'u al-Jawami' al-Ma'ruf Bi Jami' al-Kabir, (Libanon : Dar alSa'adah Lil Thaba'ah, 2005 M/ 1426 H), jilid ke-6, 616.

${ }^{26}$ Yusuf Abdurrahaman al-Mizzi, Tuhfaz alAsyraf Bi Ma'rifat al-Athra, (Beirut : Maktabah alIslamiyah, 1983 M/1403 H), jilid ke-8, 204. 


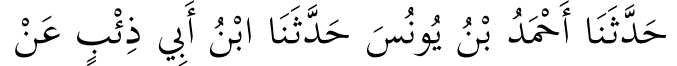

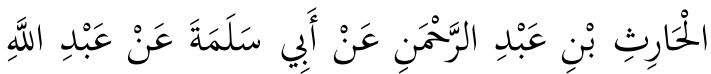

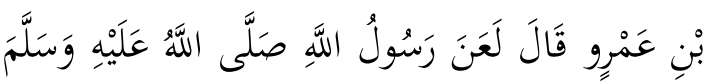

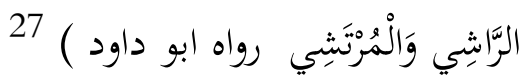

Ahmad bin Yunus menceritakan kepada kami, Ibnu Abi Dzi'bi menceritakan kepada kami, dari Harits bin Abdurrahman, dari Abi Salamah, dari Abdullah bin Umar berkata, bahwa Rasulullah Saw bersabda: "Rasulullah shallallahu 'alaihi wasallam melaknat orang yang menyuap dan yang menerima suap.” H.R. Abu Daud )

\section{Skema Sanad Jalur Imam Abu Daud}

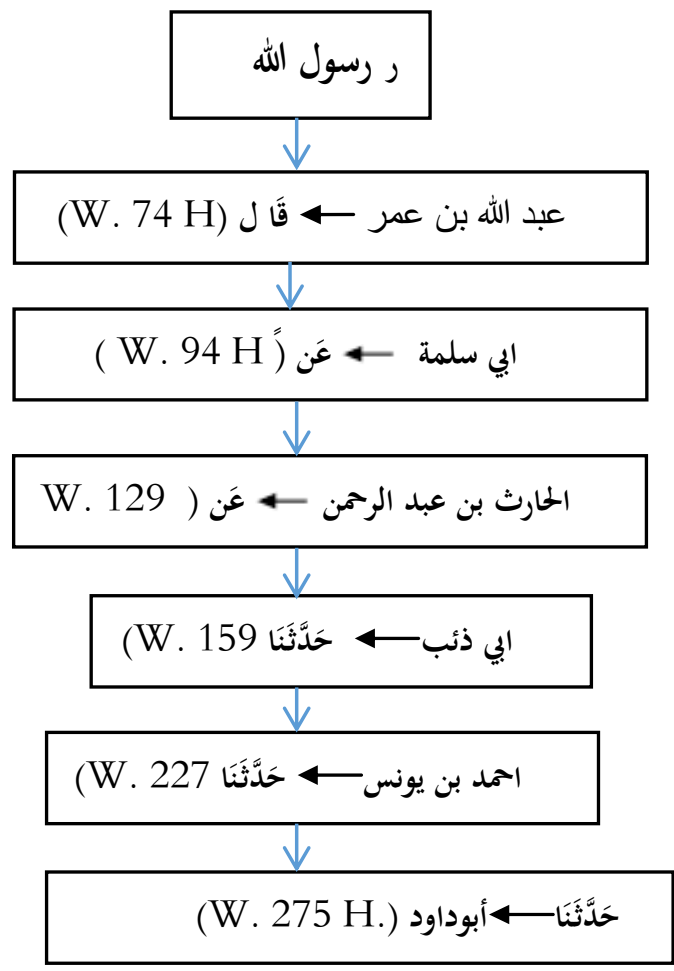

2. Dalam Kitab al-Tirmidzi dalam kitab Ahkam bab no. 9

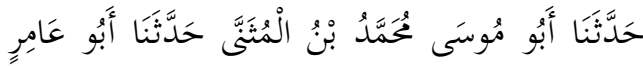

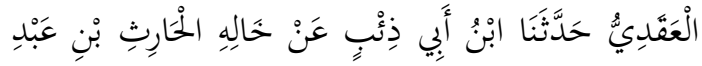

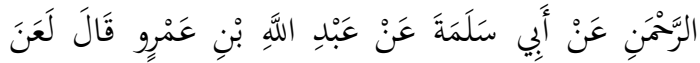

${ }^{27}$ Abu Daud Sulaiman bin al-Asy'ats alSijistani, Op. Cit, jilid 3, 291.

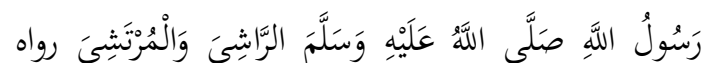

28 الترمذي

Ahmad bin Musa bin Mutsanna menceritakan kepada kami, Abu 'Amir al-'Aqdi menceritakan kepada kami, Abi Dzi'bi menceritakan kepada kami dari Harits bin Abdurrahman, dari Abi Salamah, dari Abdullah bin Umar berkata, bahwa Rasulullah Saw bersabda: "Rasulullah shallallahu "alaihi wasallam melaknat orang yang menyuap dan yang menerima suap." H.R. al-Tirmidzi )

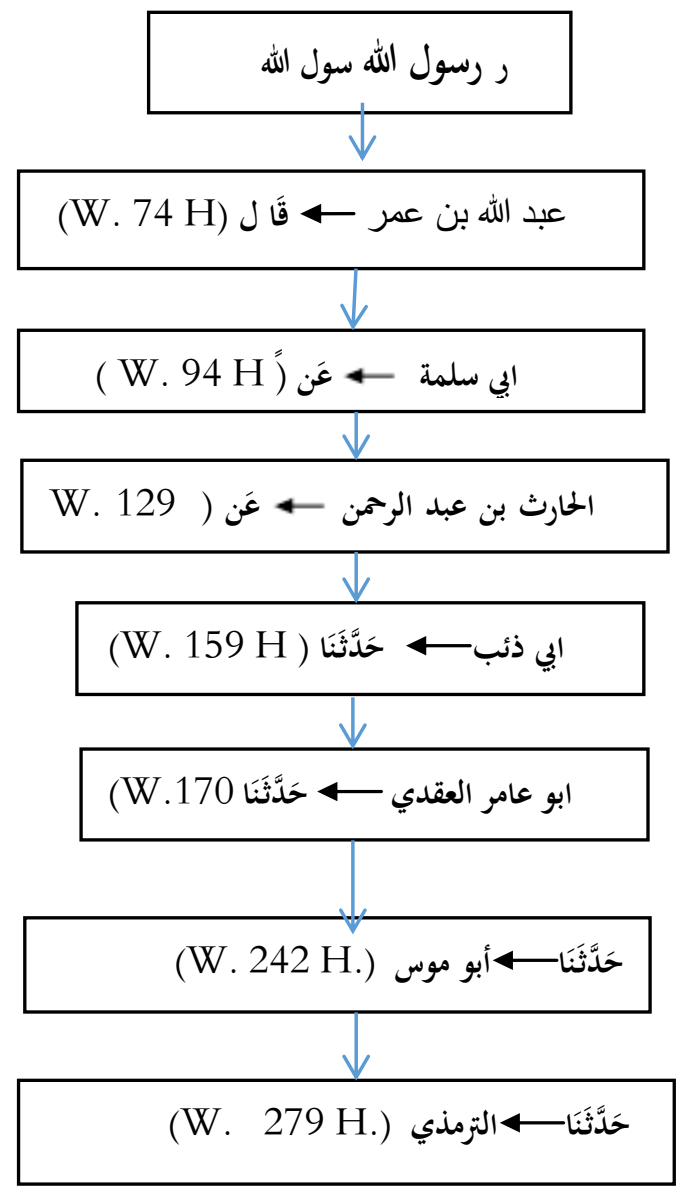

\section{Skema Sanad Jalur Imam al-Tirmidzi}

3. Dalam kitab Ibnu Majah dalam kitab Ahkam bab no. 2

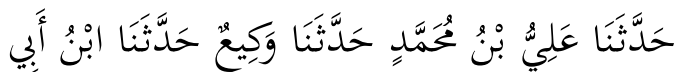

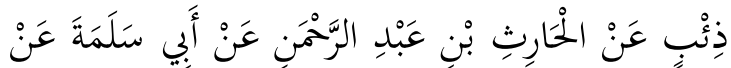

${ }^{28} \mathrm{Abu}$ 'Isa Muhammad bin 'Isa Ibnu Saurah al-Sulami al-Tirmidzi, Sunan al-Tirmidzi, (Beirut: Dar al-Fikri, 2003 M), jilid 5, 176. 
عَبْدِ اللَّهِ بْنِ عَمْرِو قَالَ قَالَ رَسُولُ اللَّهِ صَلَّى اللَّهُ عَلَيْهِ

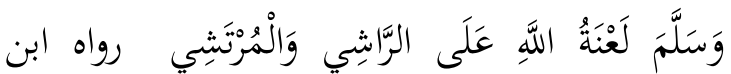
29 ماجه (20)

Ali bin Muhammad menceritakan kepada kami, Waki', menceritakan kepada kami, Abu Dzi'bi menceritakan kepada kami, dari Harits bin Abdurrahman, dari Abi Salamah, dari Abdullah bin Umar berkata, Rasulullah Saw bersabda: Allah melaknat orang yang menyuap dan yang menerima suap." ( H.R. Ibnu Majah).

\section{Skema Sanad Jalur Imam Ibnu Majah}

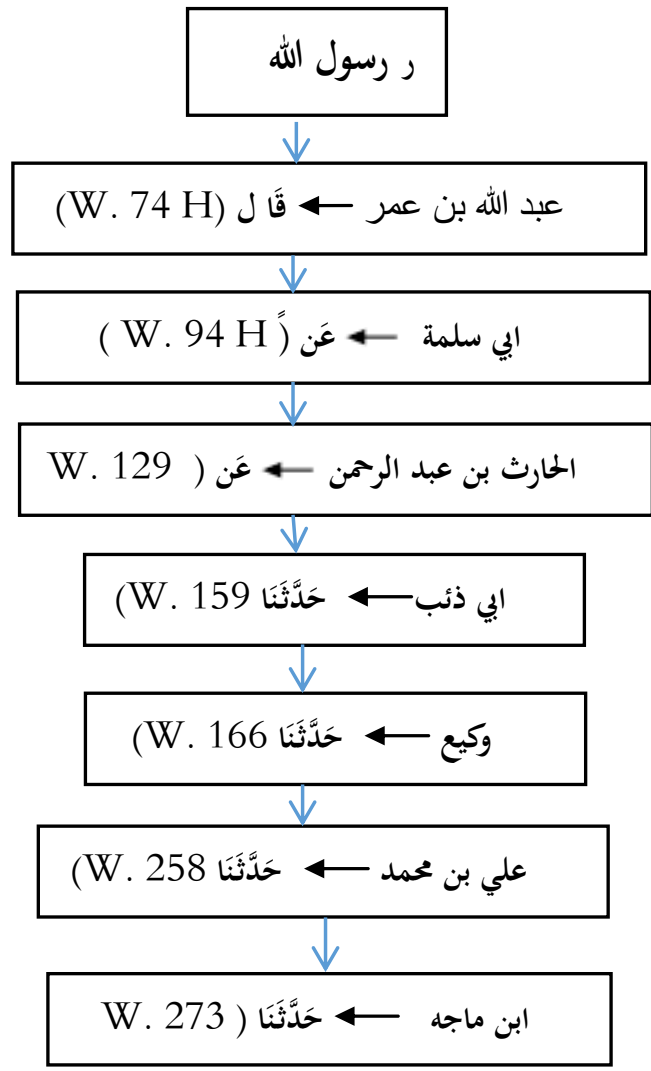

4. Dalam Kitab Ahmad bin Hanbal no. 6246

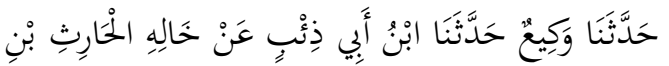

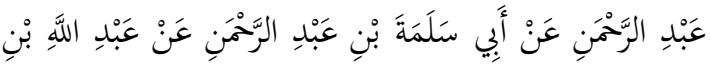

${ }^{29}$ Abi Muhammad bin Yazid Al-Qazwaini, Sunan Ibnu Majah, (Beirut Libanon : Dar Fikr, 2004), jilid 1, 727.

$$
\begin{aligned}
& \text { عَمْرِو قَالَ لَعَنَ رَسُولُ اللَّهِ صَلَّى المَّهُ عَلَيْهِ وَسَتلَّمَ الرَّاشِيَ }
\end{aligned}
$$

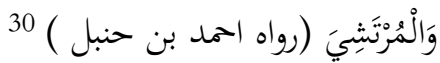

Waki', menceritakan kepada kami, Abi Dzi'bi menceritakan kepada kami, dari Harits bin Abdurrahman, dari Abi Salamah, dari Abdullah bin Umar berkata, Rasulullah Saw bersabda: Allah melaknat orang yang menyuap dan yang menerima suap." ( H.R. Ahmad bin Hanbal ).

\section{Skema Sanad Jalur Imam Ahmad bin Hanbal}

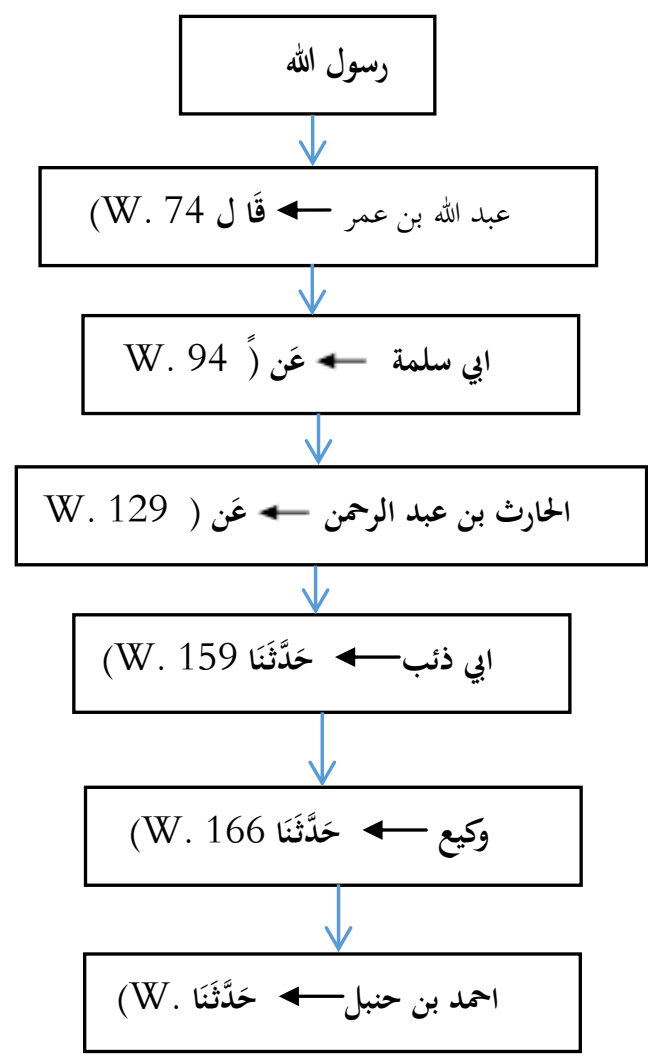




\section{Skema Gabungan Seluruh Sanad Hadis Tengtang Risywah}

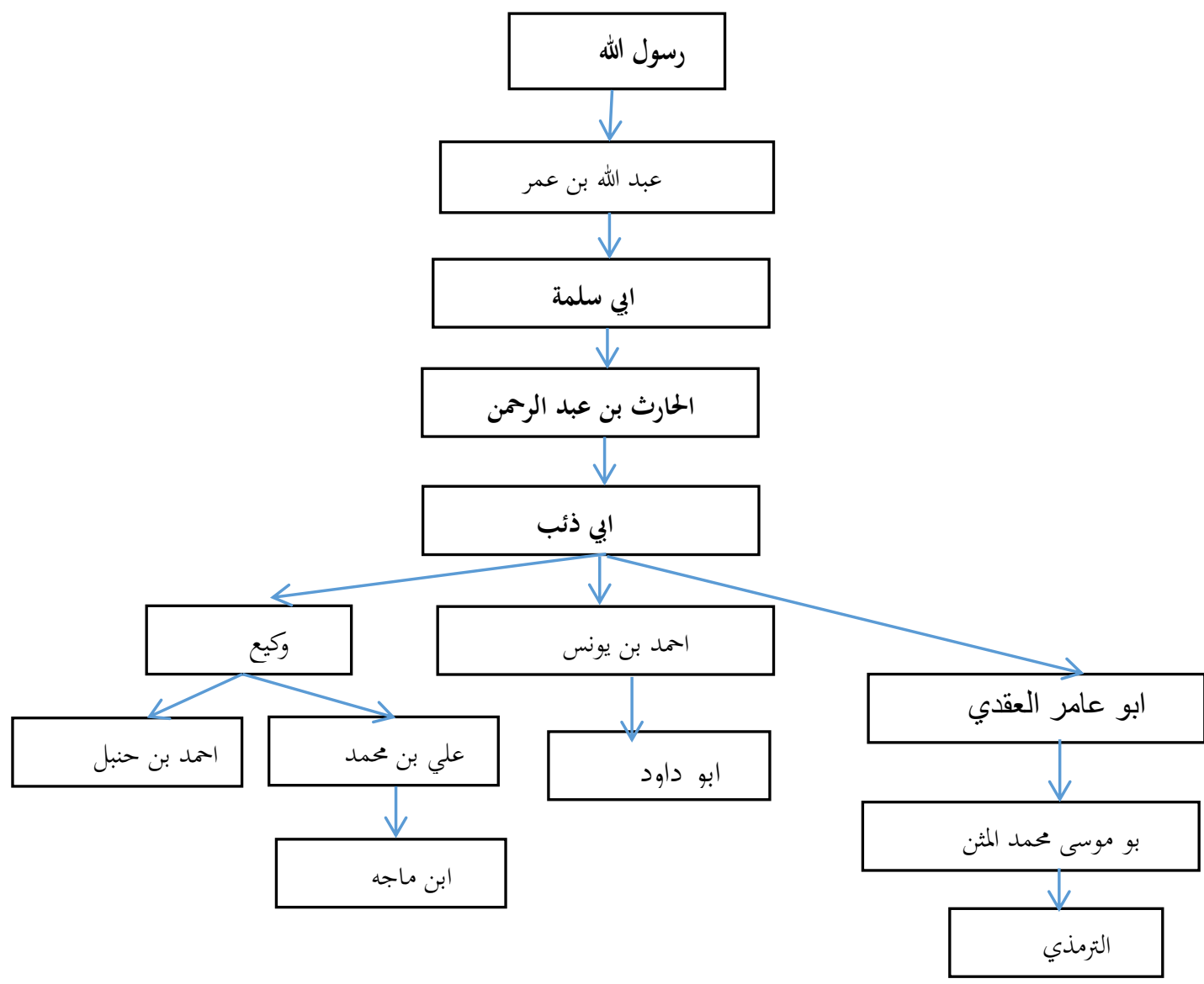

\section{Biografi Sanad Dalam Sunan Abi Daud}

Rangkaian transmiter yang terlihat dalam periwayatan hadis tersebut adalah: Abdullah bin Umar, Abi Salamah, Haris bin Abdurrahman, Abi Dzi'bi, Ahmad bin Yunus dan Abu Daud. Untuk mengetahui apakah hadis ini memenuhi unsur kesahihan sanad, maka akan dikemukakan riwayat hidup dan kepribadian para perawi tersebut.

a. Abdullah bin Umar

Nama lengkapnya adalah Abdullah bin Umar bin Khattab al-Qurasyi al-Adawiy, Abu Abdurrahman Makkiy. ${ }^{31}$. Guru-gurunya adalah Nabi SAW, Rafi' bin Khadij, Zaid bin Tsabit, Said bin Abi Waqash, dan lainlain, sedangkan murid-muridnya ialah Jubair bin Nufairin, Hakim bin Hurrah, Abu

${ }^{31}$ Jamaluddin Abu al-Hajjaj Yusuf al-Mizzi, Tahzib al-Kamal fi Asma' al-Rijal, (Beirut: Muassasah al-Risalah, 1983), jilid 10, 356.
Salamah bin Abdurrahman, Abu Bakri bin Sulaiman, dan lain-lain. Adapun komentar ulama terhadap Abdullah bin Umar adalah al-Shahãbah Kulluhum 'Udull, Abdullah bin Umar wafat tahun $74 \mathrm{H}$

b. Abi Salamah

Nama lengkapnya adalah Abu Salamah bin Abdurrahman bin 'Auf al-Qurasyi Az- Zuhriy al-Madani. ${ }^{32}$ Guru-gurunya adalah Abdullah bin Ibrahim, Abdurrahman bin Abi Said, Abdullah bin Umar bin Khattab al-Qurasyi al-Adawiy, Abdullah bin Salam, dan lain-lain, sedangkan murid-muridya adalah Usman bin Abi Sulaiman, Haris bin Abdurrahman, Yahya bin Said, Walid bi Abdullah, Muhammad bin, dan lain-lain. Adapun komentar ulama terhadap Abi Salamah adalah Abu Zur'ah mengatakan Tsiqah Hibban juga mengatkan Tsiqah. Abi Salamah wafat pada tahun $94 \mathrm{H}$.

c. Haris bin Abdurrahman

Nama lengkapnya Haris bin Abdurrahman Al-Qurasyi al-Amiri, Abu Aburrahman al-

\footnotetext{
${ }^{32}$ Jamaluddin Abu al-Hajjaj Yusuf al-Mizzi,
} Tahzib al-Kamal fi Asma' al-Rijal, jilid 21, 269. 
Madani. ${ }^{33}$ Guru-gurunya adalah Jubair bin Salamah, Salim bin Abdullah, Abi Salamah bin Abdurrahman bin 'Auf, Ibnu Abbas, dan lainlain. Murid-muridnya adalah Muhammad bin Abdurrahman bin Abi Dzi'bi, dan lain-lain. Komentar para ulama terhadap Haris bin Abdurrahman adalah al-Nasai berkata Laisa bihi Ba'sun dan Ibnu Hibban mengatakan Tsiqah. Haris bin Abdurrahman wafat pada tahun $129 \mathrm{H}$

\section{d. Abi Dzi'bi}

Nama lengkapnya adalah Muhammad bin Abdurrahman bin Mughirah bin Haris bin Abu Dzi'bi, Abu Haris al-Madani. ${ }^{34}$ Gurugurunya adalah Said bin Khalid, Said bin Sam'an, Sulaiman bin Abdurrahman, Haris bin Abdurrahman al-Qurasyi, Usman bin Muhammad, dan lain-lain. Sedangkan muridmuridnya adalah Ishaq bin Sulaiman, Ahmad bin Abdullah bin Yunus, Ishaq bin Muhammad, Hajjaj bin Muhammad, Said bin, dan lain-lain. Adapun komentar ulama terhadap Abi Dzi'bi adalah al-Nasai: Tsiqah, Abu Bakrin al-Marrudi: Tsiqah, Yahya bin Ma'in: Tsiqah, Ahmad bin Hanbal: Rajulul Shalih. Wafat pada tahun $158 \mathrm{H}$.

e. Ahmad bin Yunus

Nama lengkapnya adalah Ahmad bin Abdullah bin Yunus bin Abdullah bi Qais al-Tammimi al-Yarbu'i, Abu Abdullah alKufi ${ }^{35}$.Guru-gurunya adalah Sufyan bin Said, Muhammad bin Abdurrahman bin Mughirah bin Haris bin Abi Dzi'bi, Malik bin Anas, Ya'kub bin Abdullah, dan lain-lain. Muridmuridnya adalah Bukhari, Muslim, Ishaq bin Ibrahim, Abu Daud, Yusuf bin Musa, Musa bin Said, dan lain-lain. Adapun komentar ulama terhadap Ahmad bin Yunus adalah al-Nasai: Tsiqah, Abu Hatim: Tsiqah, Al-Ijli: Tsiqah, Ibnu Hibban: Tsiqah. ${ }^{36}$ Wafat pada tahun $227 \mathrm{H}$.

\section{f. Abu Daud}

Nama lengkapnya adalah Sulaiman bin al-Asy'ats al-Sijistani. ${ }^{37}$ Guru-gurunya adalah Ahmad bin Sa'id al-Hamdani, Ahmad

\footnotetext{
${ }^{33}$ Jamaluddin Abu al-Hajjaj Yusuf al-Mizzi,
}

Tahzib al-Kamal fi Asma' al-Rijal, jilid 4, 46.

${ }^{34}$ Jamaluddin Abu al-Hajjaj Yusuf al-Mizzi,

Tahzib al-Kamal fi Asma' al-Rijal, jilid 16, 500.

${ }^{35}$ Jamaluddin Abu al-Hajjaj Yusuf al-Mizzi,

Tahzib al-Kamal fi Asma' al-Rijal jilid 1, 182.

${ }^{36}$ Ibnu Hajar al-Asqalani, Tahzib al-Tahzib,

(Beirut : Dar al-Fikr, 1995), jilid 1, 44.

${ }^{37}$ Jamaluddin Abu al-Hajjaj Yusuf al-Mizzi, Op. Cit, jilid 1, 5. bin Abdullah bin Yunus bin Abdullah bi Qais al-Tammimi al-Yarbu'i, dan lain-lain. Muridmuridnya adalah Al-Tirmidzi, Ibrahim bin Hamdan bin Ibrahim, Abu 'Isa Ishaq bin Musa, dan lain-lain. Adapun komentar ulama adalah Al-Khalili: Tsiqah, Abi Hatim al-Razi: $L a$ $B a$ 'sa Bih, al-Tirmidzi: La Ba'sa Bih, alNasai: Tsiqah. Wafat pada tahun $275 \mathrm{H}$.

Penulis menyimpulkan bahwa kredibilitas perawi hadis ini memenuhi kriteria perawi hadis shahih, maka hadis dari jalur Abu Daud dari segi kualitas berstatus shahih. Dan sesuai menurut imam Abu al-Thayyib Muhammad Syamsul Haq al-Azim Abadi dalam kitab 'Aun al-Ma'bud syarah Sunan Abu Daud dalam riwayat Sunan Abi Daud statusnya adalah Shahih ${ }^{38}$ dan dapat dijadikan dalil atau hujjah. ${ }^{39}$

\section{Syarah Hadis}

Kata لعن dalam hadis bermakna jauh dari rahmat Allah. Sedangkan kata الراشي orang yang memberikan suap atau sogokan kepada seseorang untuk meluruskan urusan atau untuk maksud mengabulkan putusan hakim. Dengan ungkapan lain, orang yang memberikan suatu hadiah untuk menjadikan yang salah tidak salah, yang tidak berhak jadi berhak. $^{40}$

Sedangkan kata المرتش dalam hadis berarti orang yang mengambil sogokan. Secara tegas dalam hadis ada larangan memberikan sogok atau menerima sogok. Di dalam alQur'an surah al-Baqarah ayat 188 Allah dengan tegas melarang seseorang memakan sesuatu yang bukan haknya dengan cara yang batil tidak benar) dan melarang orang membawa perkara kepada hakim dengan tujuan untuk mendapatkan harta orang lain

38 Hadis Shahih ialah hadis yang bersambung sanadnya, orang-orangnya dari awal sampai akhir adil, kuat hapalanya, tidak bertentangan ayat al-Qur'an, matannya tidak bertentangan dengan matan hadis yang lebih tinggi derajatnya, dan tidak bertentangan dengan akal dan tidak bertentangan juga dengan kenyataan, lihat : Zainal 'Abidin, Mushthalah Hadis, (Bandung : Setia Karya, 1984), 29-30.

${ }^{39}$ Abu al-Thayyib Muhammad Syamsul Haq al-Azim Abadi, 'Aun al-Ma'bud Syarah Sunan Abu Daud, (al-Qahirah : Dar al-Hadis, 2001), jilid 6, 416.

${ }^{40} \mathrm{Abu}$ al-Thayyib Muhammad Syamsul Haq al-Azim Abadi, 'Aun al-Ma'bud Syarah Sunan Abu Daud 417. 
dengan jalan berbuat dosa. Risywah salah satu cara pemberian yang tidak dilandasi oleh keikhlasan untuk mencari kerelaan Allah. Melainkan untuk tujuan yang bertentangan dengan tuntunan atau tuntutan syari'at Allah.

Oleh sebab itulah didalam hadis ini dinyatakan bahwa orang yang memberi dan menerima suap mendapat laknat dari Allah dan Rasulnya. Hal ini disebabkan karena pemberi suap mendorong penerima melalaikan tugasnya sebagai penegak kebenaran, memudahkannya memakan sesuatu yang bukan miliknya secara batil. Sedangkan penerima sogok mendapat laknat karena mengambil harta orang lain secara tidak benar.

Menurut Ibnu al-Qayyim apabila pemberian dimaksudkan untuk menuntut hak atau menghindarkan diri dari kezhaliman maka menurut beliau hal tersebut tidak apa-apa dan bukan kategori suap yang dilaknat. ${ }^{41}$ Hanya saja pendapat ini dibantah oleh al-Syaukani yang mengatakan bahwa pengkhususan tentang pemberian untuk menuntut hak tidak memiliki dasar yang jelas, yang benar menurut beliau kembali kepada keumuman hadis yang menyebutkan larangan segala bentuk pemberian dalam bentuk suap. Ibnu Qudamah dalam kitabnya al-Mughni, ia berkata:

" Adapun suap-menyuap dalam masalah hukum dan pekerjaan apa saja) maka hukumnya haram tidak diragukan lagi. ${ }^{42}$

Syeikhul Islam Ibnu Taimiyah menyebutkan bahwa para ulama telah mengatakan:

" Sesungguhnya pemberian hadiah kepada wali amri orang yang diberikan tanggung jawab atas suatu urusan untuk melakukan sesuatu yang tidak diperbolehkan, ini adalah haram, baik bagi yang memberikan maupun menerima hadiah

41 Amrul Muzan, Jurnal Hukum Islam, ( Pekanbaru : Fakultas Syari'ah dan Ilmu Hukum UIN Suska Riau, 2008 ), 148.

42 Ibnu Qudamah al-Maqdisi, al-Mughniy, (Lebanon : Bait al-Afkar al-Dauliyyah, 2004), jilid 23, 28. itu, dan ini adalah suap yang dilarang Nabi Saw. $^{43}$

Al-Shan'aniy dalam Subulussalam juga menegaskan: "Dan suap-menyuap itu haram sesuai Ijma', baik bagi seorang qadhi/hakim, bagi para pekerja yang menangani shadaqah atau selainnya. Sebagaimana firman Allah Ta'ala, "Dan janganlah sebahagian kamu memakan harta sebahagian yang lain di antara kamu dengan jalan yang bathil dan janganlah) kamu membawa urusan) harta itu kepada hakim, supaya kamu dapat memakan sebahagian daripada harta benda orang lain itu dengan jalan berbuat) dosa, padahal kamu mengetahui. [QS. AlBaqarah: 188]." 44

Dalam kitab I'ânatuth Thâlibîn, Sayyid Abû Bakr menulis:

"Haram bagi qadhi imam) menerima hadiah dari orang yang tidak pernah memberinya hadiah sebelum ia menjadi qadhi, atau pernah tapi ia menambahkan jumlah atau jenisnya, hal ini bila terjadi dalam wilayah kepemimpinannya, adapun dari orang yang diluar lingkungan kepemimpinannya maka dibolehkan, dan haram juga menerima hadiah dari orang yang mempunyai keterlibatan kasus, atau orang yang menjadi lawan politik baginya, dikarenakan hal ini nanti bisa mengakibatkan imam akan cenderung kepadanya dan mendukung segala kehendaknya dan dapat melemahkan dirinya dalam memutuskan keputusan yang benar dan adil. $^{45}$

Risywah (suap) itu haram walaupun untuk memperoleh hak yang mesti diterima. Sebab kalau paham ini kita pake kita akan ikut mendorong lanjutnya korupsi. Pemberian semacam ini, meskipun dilakukan oleh pemberi untuk mendapatkan haknya yang sah tetap akan merusak sistem pelayanan publik, berupa memburuknya kualitas pelayanan tersebut.

43 Syaikh al-Islam Ibnu Taimiyah, Majmu' Fatawa, (Kairo : Maktabah Dar al-Salam, t.thn), jilid $31,161$.

${ }^{44}$ Imam al-Shan'ani, Subul al-Salam Syarah Bulugh Maram, ( Riyadh : Maktabah Nizar Mushtafa al-Baz, 1995 ), jilid 2, 26.

${ }^{45}$ Sayyid Abu Bakar, I'anatuth Thalibin, (Semarang: Toha Putra, 2000 ), 47 
Walaupun ada yang membolehkan memberikan suap atau menerima suap untuk memperoleh hak yang mesti diterima, tetap saja akan semakin rentan terhadap maraknya praktek sogok-menyogok, kolusi, korupsi, dan nepotisme bahkan akan menumbuhsuburkan praktek mafia peradilan yang terpuji.

Tradisi atau pandangan yang menganggap tidak termasuk suap yang diancam laknat dalam hadis tentang risywah, jika penyuapan dilakukan untuk memperjuangkan haknya atau untuk menolak ketidakadilan yang dirasakannya harus dipertimbangkan. Sebab persoalan memperjuangkan hak dan menolak ketidakadilan atau kezaliman ini merupakan sesuatu yang sangat abstrak dan sulit dicari tolak ukur dan standarisasinya.disamping itu, situasi dan kondisi Indonesia yang saat ini sedang berjuang dan berusaha kuat memberantas korupsi akan terganggu dengan pandangan dibolehkannya suap, sogok, atau gratifikasi yang bertujuan untuk memperjuangkan hak dan menolak ketidakadilan atau kezaliman.

Risywah adalah pekerjaan yang dilarang dan pelaku dan penerimanya adalah dilaknat. Walaupun kadang tampak pemberian suap ini seperti hadiah tetapi sesungguhnya suap akan selalu terkait dengan permasalahan hukum atau pelaksanaan hak-hak dan kewajiban orang yang memberi dan yang diberi. Dalam hal pemberian hadiah adalah pekerjaan mubah yang dibolehkan, akan tetapi jika pekerjaan yang bersifat mubah ini menyebabkan ke arah penyuapan atau menyebabkan tidak adilnya seseorang dalam menetapkan hakhak dan kewajiban atau tidak adil dalam menetapkan hukum, maka hukum pemberian ini bias menjadi haram.

\section{KESIMPULAN}

Setelah penulis melakukan takhrij terhadap hadis-hadis nabi Saw tentang risywah maka hadisnya berkualitas shahih dan dapat dijadikan hujjah atau dalil. Pemberian yang dibolehkan dalam Islam adalah berbentuk hibah. Pada dasarnya sebagaimana hukum transaksi muamalah lainnya bahwa hibah adalah perkara mubah jika selama dalam bentuknya tidak melanggar apa yang disebutkan Allah Swt dan Rasulnya tentang kategori-kategori pelanggaran yang menyerupai risywah. Para ulama berbeda pendapat dalam memahami hadis risywah. Menurut Ibnu al-Qayyim apabila pemberian dimaksudkan untuk menuntuk hak atau menghindarkan diri dari kezhaliman menurut beliau hal tersebut tidak apa-apa. Sedangkan menurut Ibnu Qudamah, Ibnu Taimiyah, Imam alShan'ani, Syyin Abu Bakar suap-menyuap dalam masalah hukum dan pekerjaan apa saja) maka hukumnya haram tidak diragukan lagi.

\section{DAFTAR PUSTAKA}

'Abidin, Zainal. Mushthalah Hadis, Bandung: Setia Karya, 1984.

Abadi, Abu al-Thayyib Muhammad Syamsul Haq al-Azim. 'Aun al-Ma'bud Syarah Sunan Abu Daud, al-Qahirah: Dar alHadis, 2001.

Abu Bakr, Sayyid. I'anatuth Thalibin, Semarang: Toha Putra, 2000.

Ahmad, Abu Abdul Halim. Dampak Suap dan Bahayanya Tinjauan Syari'ah dan Sosial, Jakarta: Pustaka al-Kautsar, 1996.

Al-'Asqalanị, Ahmad bin 'Ali Ibn Hajar. Fath al-Bari syarh Sahih al-Bukhari, Riyaḍ: Dar al-Salam, 2001 M/ 1421 H.

$$
\text { Tahzib al-Tahzib, }
$$

Beirut: Dar al-Fikr, 1995.

Al-Gharyani, Al-Shadiq Abdurrahman. Fatwa-Fatwa

Muamalah

Kontemporer, Surabaya: Pustaka Progresif, 2004.

Al-Maqdisi, Ibnu Qudamah. al-Mughniy, Lebanon: Bait al-Afkar al-Dauliyyah, 2004.

Al-Mizzi, Jamaluddin Abu al-Hajjaj Yusuf. Tahzib al-Kamal fi Asma' al-Rijal, Beirut: Muassasah al-Risalah, 1983. Tuhfaz al-Asyraf Bi Ma'rifat al-Athra, Beirut: Maktabah al-Islamiyah, $1983 \mathrm{M} / 1403 \mathrm{H}$.

Al-Qaradhawị,Yusuf. al-Halalwa al-Haram fi al-Islam, Beirut: al-Maktabah alIslamiyah, 1980.

Al-Qazwaini, Abi Muhammad bin Yazid. Sunan Ibnu Majah, Beirut Libanon: Dar Fikr, 2004. 
Al-Shan'ani, Muhammad bin Ismail alkahlani. Subul al-Salam Syarah Bulugh Maram, Riyadh: Maktabah Nizar Mushtafa al-Baz, 1995.

Al-shaybani, Ahmad bin Muhammad Hanbal abu Abdullah. Musnad Ahmad bin Hanbal Beirut, Dar Al-Kitab Al'Alamiyyah.

Al-Sijistani,Abu Daud Sulaiman bin alAsy'ats. Sunan Abi Daud, Beirut: Maktabah Ashriyah, 2003.

Al-Suyuthi, Jalaluddin. Jam'u al-Jawami' al-Ma 'ruf Bi Jami' al-Kabir, Libanon: Dar al-Sa'adah Lil Thaba'ah, 2005 M/ $1426 \mathrm{H}$.

Al-Tirmidzi, Abu 'Isa Muhammad bin 'Isa Ibnu Saurah al-Sulami.Sunan alTirmidzi, Beirut: Dar al-Fikri, 2003 M.

Azmi, Muhammad Ulul. Pilkada dan Risywah Dalam Perspektif Siyasah Syar'iyyah, Skripsi S1 Fakultas Syari'ah dan Hukum, (Yogyajakarta : Fakultas Syari'ah dan Hukum UIN Kalijaga, 2010), 2.

Baqi, Muhammad Fu'ad Abdul. Miftah Kunuz al-Sunnah, Kairo: Dar al-Hadis, $2007 \mathrm{M} / 1428 \mathrm{H}$.

Departemen Agama RI, Mushaf Mufassir, Bandung: Jabal, 2009.

Umar, Ahmad Mukhtar. Mu'jam al-Lugah al-'Arabiyah al-Mu'asirah, Kairo: 'Alam al- Kutub, 2008.

Wensinck, A.J. al-Mu'jam al-Mufahras li Alfas al-Hadist al-Nabawi Laiden: Maktabah Briil, 1962.

Ya'la, Abu. Musnad Abu Ya'la, Beirut: Dar al-Ilm al-Malayin, t.thn.
Ibn Manzhur, Muhammad ibnu Makram. Lisanul 'Arab, Beirut: Dar al-Shadur, $1374 \mathrm{H}$.

Ibn Taimiyah, Taqiyuddin ahmad. Majmu' Fatawa, Kairo: Maktabah Dar alSalam, t.thn.

Irfan, Nurul. Korupsi dalam Hukum Pidana Islam, Jakarta: Amzah, 2012.

Isma'il, Syuhudi. Cara praktis Mencari Hadis, Jakarta: Bulan Bintang, 1991.

Muhsin, Abdullah Bin Abd. Suap Dalam Pandangan Islam, trjmh. Muchotob Hamzah dan Subakir Saerozi, Jakarta: Jakarta: Gema Insani Press, 2001.

Munawwir, Ahmad Warson. Kamus ArabIndonesia, Surabaya: Pustaka Progressif, 2002 .

Mustafa, Ibrahim \& Dkk. al-Mu'jam alWasith, Istanbul: al-Maktabah al Islamiyah, 1972.

Muzan, Amrul. Julnal Hukum Islam, Pekanbaru: Fakultas Syari'ah dan Ilmu Hukum UIN Suska Riau, 2008 .

Tim Penulis Depdikbud RI, Kamus Besar Bahasa Indonesia, Jakarta: Pustaka Panjimas, 1980.

Tim Penyusun Undang-Undang Republik Indonesia, Tindak Pidana Suap, www.pih.deplu.go.id, diakses 17/02/2013. 
